\title{
TITLE:
}

\section{REVISION OF JAPANESE CUBOMEDUSAE}

$\operatorname{AUTHOR}(S)$ :

Uchida, Tohru

\section{CITATION:}

Uchida, Tohru. REVISION OF JAPANESE CUBOMEDUSAE.

PUBLICATIONS OF THE SETO MARINE BIOLOGICAL LABORATORY 1970, 17(5): 289-297

ISSUE DATE:

1970-02-21

URL:

http://hdl.handle.net/2433/175610

RIGHT: 


\title{
REVISION OF JAPANESE CUBOMEDUSAE
}

\author{
TOHRU UCHIDA \\ Biological Laboratory, Imperial Household, Tokyo and \\ Zoological Institute, Hokkaido University, Sapporo
}

With 5 Text-figures

In 1929 the writer reported two Cubomedusae, Charybdea rastonii and Tamoya alata from Japan. Concerning these species, the identification of the former species is correct, but while studying on the Carybdeidae, it has been revealed that the young medusae described as the young forms of Tamoya alata seem to be nothing but the small Carbdeid medusa Carybdea sivickisi Stiasny. Moreover, thanks to Bigelow's report (1938), it has been clear that Carybdea alata is a distinct species and does not belong to the genus Tamoya. Therefore, the Japanese Tamoya was identified by the present writer (1947) with T. bursaria which is widely distributed in the Pacific. But the Pacific species belongs possibly to the Atlantic species T. haplonema as KramP (1968) pointed out, thence reduction of two species of Tamoya to the single tropical cosmopolitan species, T. haplonema. Recently many immature medusae of this species were collected in the vicinity of the Aitsu Marine Biological Station attached to the Kumamoto University in Ariake Bay and the writer was able to study the metamorphosis of T. haplonema and made out that Tamoya-stage is gradually formed from the Carybdea-stage. Furthermore, Tripedalia cystophora CONANT hitherto found in Jamaica and the Philippines was found for the first time at the same locality. Then, Japanese Cubomedusae are listed as below. They all belong to the family Carybdeidae.

1. Carybdea rastonii HAACKE

2. Carybdea sivickisi STIASNY

3. Tamoya haplonema F. MÜLLER

4. Tripedalia cystophora CoNANT

In comparision with medusae of Tamoya the writer could examine through the kindness of Dr. T. Tokioka a good preserved specimen of the gigantic species, Carybdea alata Reynaud obtained off Cape Town and preserved in the Seto Marine Biological Station.

\section{Carybdea rastonii HAACKE}

Carybdea rastonii: KRAMP, 1961, p. 305-306; Charybdea rastonii: UCHIDA, 1929, p. 157-171.

Publ. Seto Mar. Biol. Lab., XVII (5), 289-297, 1970. (Article 16) 
The medusa is common in Japanese waters, from Hokkaido to Kyushu. As it occurs from July to September, it is injurious to sea-bathers, but its harm is not so serious. YAtsu (1917) reported the reaction of this medusa to light. Y. K. OKadA $(1927)^{1)}$ observed the segmentation of egg and reared the planula to a three-tentacled scyphopolyp. Uchida (1929) described the metamorphosis of the medusa from the youngest stage to the adult.

\section{Carybdea sivickisi STIASNY}

(Text-fig. 1)

Charybdea sivickisi: STIASNy, 1926, p. 240-243, figs. 1-4;

Charybdea spec.: StiAsny, 1922, p. 516-517, fig. 1;

Tamoya alata: UcHIDA, 1929 (in part), p. 177-180, figs. 86-88.

In the previous paper (1929) the writer described in the part of metamorphosis of Tamoya alata (p. 177-180) a few small cubomedusae as young forms of the species above given. Recently the writer could examine fair numbers of young specimens of Tamoya haplonema, he found his errors in the previous paper. The specimens described at that time as young medusae of Tamoya are, in all probabilities, identified with Carybdea sivickisi STIASNy which were recorded by STIASNy (1922 and 1926) from the Gulf of Siam and from Puerto Galera, Mindoro, the Philippines. This species is a premature medusa and though small in size, has well-developed gonads. The top of exumbrella is slightly concave and pedalia are weakly developed. The gonads seem to develop at first in the upper part of the interradial suture and gradually elongate downwards with the development of the medusa. There were recorded several specimens of this species as will be given, following its developing stages.

Stage A (Fig. 86, UchidA). Bell $2 \mathrm{~mm}$ high and $1.6 \mathrm{~mm}$ wide. Gastral filaments five in each interradius. No pedalia. Collected at Seto, Japan.

Stage B (Fig. 87, UchidA). Bell $3 \mathrm{~mm}$ high and $2.5 \mathrm{~mm}$ wide. Formation of furrows on the bell top. Gastral filaments about 10. Velar canals absent. Gonads as 8 flat round bodies in 4 pairs. Collected at Seto.

Stage C (Fig. 88, UchidA). Bell $4 \mathrm{~mm}$ high and $4 \mathrm{~mm}$ wide. Gastral filaments increased more than in the stage B. Velar canals simple, 2 pairs in each quadrant. No pedalia. Collected at Seto.

Stage D (Fig. 1, Stiasny, 1922). Bell $10 \mathrm{~mm}$ high. Gastral filaments in bushes. Velar canals 2 pairs in each quadrant. Pedalia slightly developed. Gonads developed as 8 leaf-shaped bodies extending from the upper corner over than half the height of bell. Collected from the Gulf of Siam.

Stage E (Figs. 1-4, Stiasny, 1926). Bell 10-12 $\mathrm{mm}$ high and 12-14 mm wide. Gastral filaments repeatedly branched and became numerous. Velar canals 2 pairs

1) Bull. Biol. d. France et Belgique, T. 61 (1927), p. 241-249. 

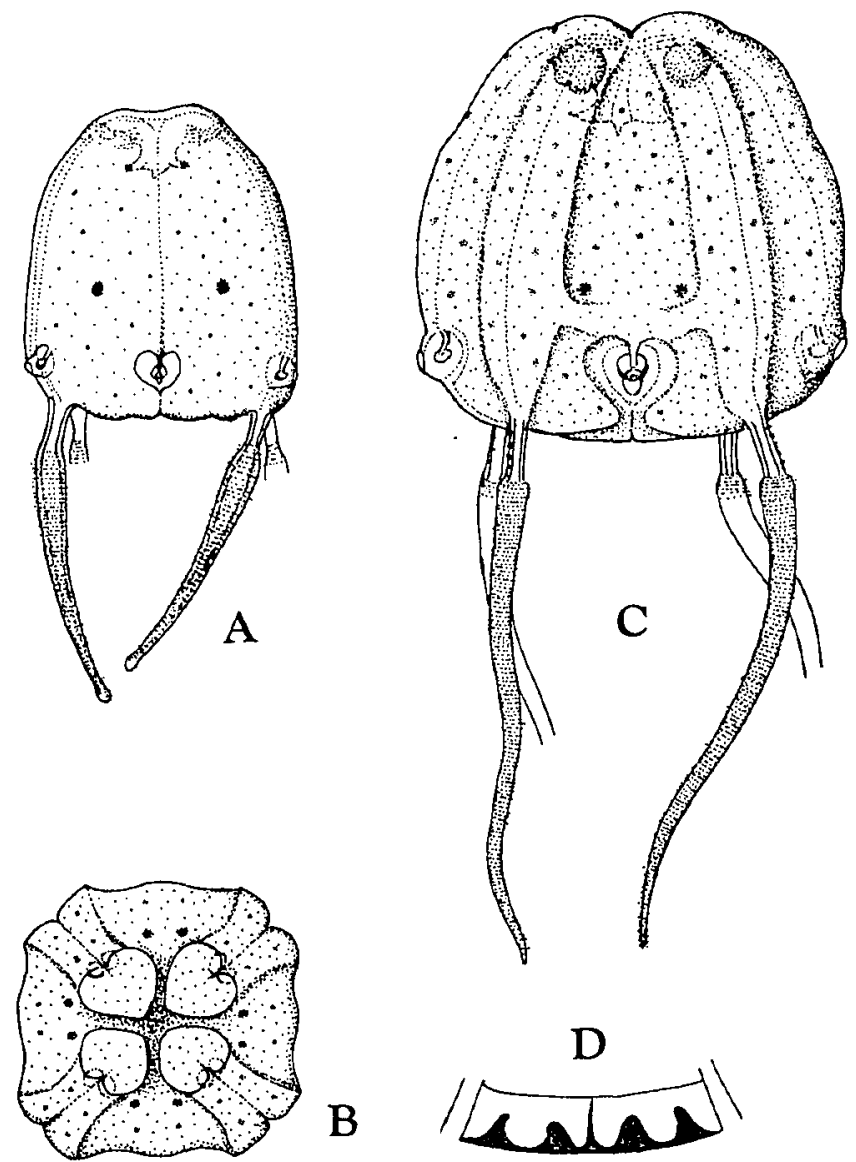

B

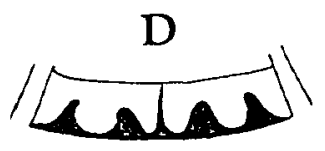

Fig. 1. Carybdea sivickisi Stıasny; A. A young medusa, $2 \mathrm{~mm}$ high and $1.6 \mathrm{~mm}$ wide. B. Aboral view of a young medusa, $3 \mathrm{~mm}$ high and $2.4 \mathrm{~mm}$ wide. C. A medusa, $4 \mathrm{~mm}$ high, with apical gonads. D. Velarium of the medusa (c), showing velar canals

in each quadrant, each canal giving rise to 4 or 5 short branches. Pedalia, though narrow, already developed. Gonads developed as 8 leaf-shaped bodies in the middle portion of interradial sutures. Bell prismatic, four-sided. Exumbrella sprinkled with many prominent nematocyst clusters. Collected at Puerto Galera, Mindoro, the Philippines.

\section{Carybdea alata REYNAUD}

(Text-fig. 2)

Carybdea alata: Bigelow, 1938, p. 144-150.

Carybdea alata: KRAMP, 1961, p. 304-305. 
A single well preserved specimen, $65 \mathrm{~mm}$ high and $72 \mathrm{~mm}$ in the broadest part, was collected off Cape Town on March 10, 1958 by the first Antarctic Soya Research Expedition, preserved in formalin and now deposited at the Seto Marine Biological Station. The outline from aboral view is rather round but four-sided, with four pairs of interradial ridges. Between the interradial ridges runs an interradial furrow which leads to the base of the tentacles. Jelly fairly thick and rigid. Exumbrella

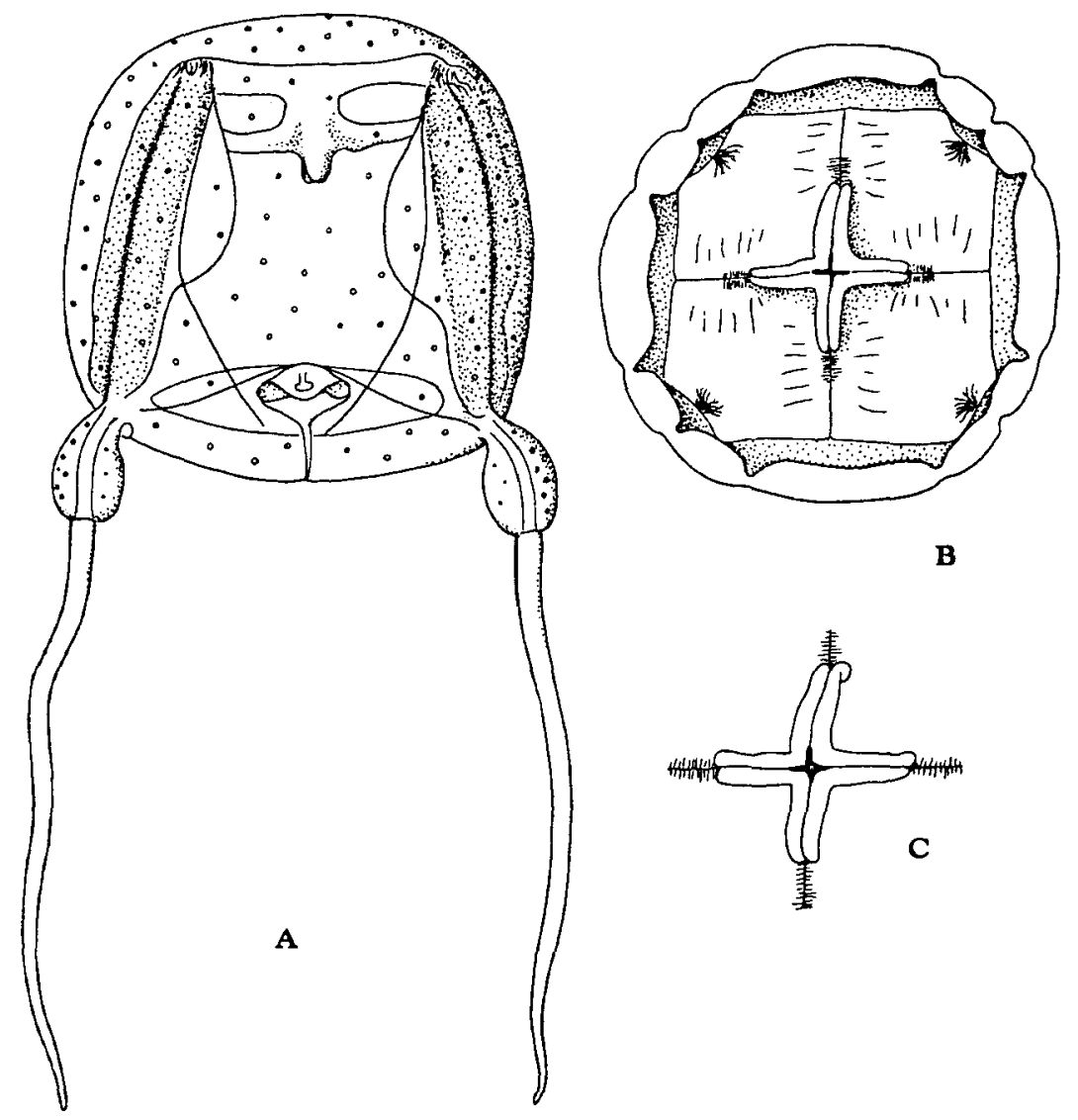

Fig. 2. Carybdea alata Reynaud, $65 \mathrm{~mm}$ high and $72 \mathrm{~mm}$ wide; A. Side view. B. Oral view of upper half part. C. Oral view of manubrium, showing perradial white transversal ridges.

sprinkled with remnants of many prominent nematocyst clusters. Subumbrella marked with subumbrellar muscles. Manubrium suspended by a rather short peduncle and provided with four well-developed lips, $29 \mathrm{~mm}$ long and a central mouth from which runs a furrow along the middle line of the lips. Stomach flattened and squarish. The sensory niches, situated $15 \mathrm{~mm}$ above the bell margin, are each protected by two covers, the upper and lower ones, containing a pedunculated sensory 
organ under the upper cover. From the sensory organ a pair of nerve cord run to the base of tentacles. Velar canals in the velarium broadly separated in two groups, the inner and the outer ones, the inner one giving rise to two main branches and the outer sending out four branches; these branches repeatedly branching further and forming an irregular and complicated arboreous mesh. Pedalia $31 \mathrm{~mm}$ long and $15 \mathrm{~mm}$ wide, each like an asymmetrical leaf in shape, with a canal leading to the canal of tentacles which are reddish in colour and larger than the bell-height in this preserved specimen. On the subumbrellar roof are found four perradial streaks which are formed by thickened subumbrellar epithelium, giving rise to numerous short transversal ridges, showing a white colour especially markedly near the central portion. There are, however, no sign of mesenteries. Branched gastral filaments are grouped at the interradial upper corners of the stomach. Gonads $54 \mathrm{~mm}$ long and $18 \mathrm{~mm}$ wide in the widest portion, each forming a leaf-like lamella on both sides of the interradial suture. The upper half of each gonad is relatively wide but the lower half becomes rapidly narrowed. The gonads do no show any transversal foldings which are seen in those of Tamoya.

The species has not yet been found in Japanese waters.

\section{Tamoya haplonema F. MƯLLER}

(Text-figs. 3 and 4 )

Tamoya haplonema: Kramp, 1968, p. 69-70; Bigelow, 1938, p. 151-155;

Tamoya alata: UchIDA, 1929, p. 172-177;

Tamoya gargantua: KRAMP, 1956, p. 237-240;

Tamoya bursaria: UchidA, 1947, p. 314-316.

Since the publication of BIGELow's paper (1938), which pointed out the separation of Carybdea alata as a distinct species from the genus Tamoya, it has been generally admitted that there are two species of Tamoya: T. haplonema in the Atlantic and $T$. bursaria in the Pacific. On account of scarcity of specimens the morphological differences between these two species are not conclusive but they have been kept separate by their distribution. According to Bigelow (1938) Tamoya bursaria is a nomen nudem and he accordingly proposed that the species must be probably named as $T$. gargantua. In 1956 KRAMP who examined the specimens from the Iranian Gulf adopted the name $T$. gargantua for $T$. bursaria, basing on BIGELow's paper. KRAMP (1961) listed in his synopsis the two species; $T$. gargantua from the Indo-Pacific and T. haplonema from the Atlantic. Recently KRAMP (1968) who examined medusae belonging to Tamoya collected by the Galathea Expedition 1950-52 from the IndoPacific and the East-Atlantic, came to the conclusion that the two species will be united to the one species, Tamoya haplonema Müller. Judging from the fact that such tropical characteristic cubomedusae as Carybdea alata and Tripedalia cystophora are widely distributed in both the Atlantic and Pacific, KRAmP's conclusion seems to be 
approvable and is followed here by the present writer. But it is very difficult to identify scyphomedusae only by preserved adult specimens. Therefore, the definite conclusion must be reserved till their life-histories are studied out.

Recently the writer could examine a lot of young living or preserved specimens of this species which commonly occurs in the vicinity of the Aitsu Marine Biological Station. These young medusae appear from the beginning of August to September. In autumn fairly developed adult medusae are found. The youngest medusa examined by the writer is $10.5 \mathrm{~mm}$ high and $9 \mathrm{~mm}$ wide (Fig. 3, A). Nematocyst

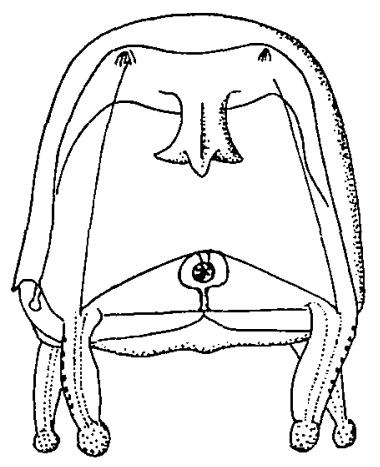

A

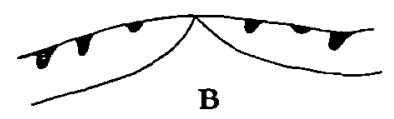

Fig. 3. Tamoya haplonema MülLER; A. The youngest medusa, $10.5 \mathrm{~mm}$ high and $9 \mathrm{~mm}$ wide, without gonads and mesenteries. B. Velar canals of the medusa. C. A young medusa, $18 \mathrm{~mm}$ high and $16 \mathrm{~mm}$ wide, with thin narrow lamellar gonads, anlages of mesenteries not well developed. D. Velar canals of the medusa.

clusters on the exumbrella not so prominent. Pedalia slightly developed and $4 \mathrm{~mm}$ long, with prominent nematocyst clusters arranged on the axial edge. Statocysts situated at the level $1.9 \mathrm{~mm}$ above the bell-margin and without cover. Velarium provided with 3 simple short velar canals in each octant. Gastral filaments present. Neither sign of gonads nor interradial mesenteries. In a medusa, $15 \mathrm{~mm}$ long and 15 $\mathrm{mm}$ wide, pedalia become wider and statocysts provided with the upper short cover. Velarium furnished with 4 simple short velar canals in each octant, a few of these 


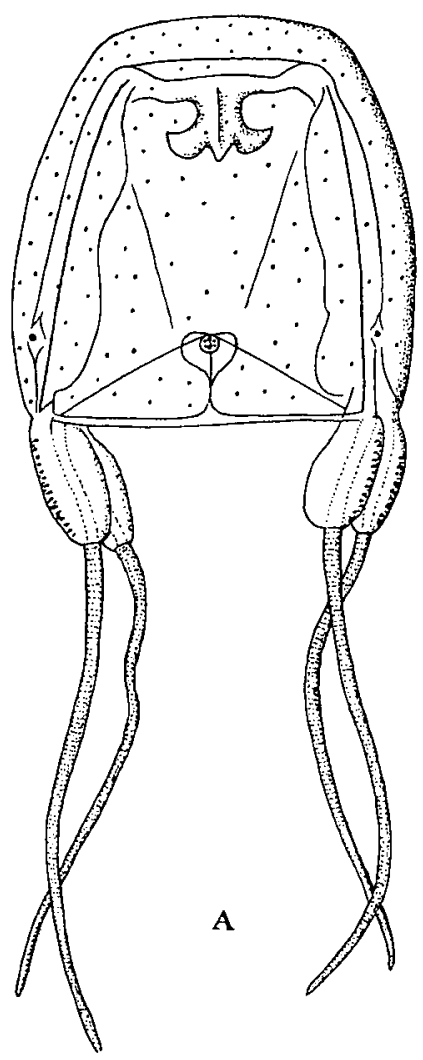

canals being bifurcated. Neither sign of gonads nor sign of interradial mesenteries. In a medusa, $16 \mathrm{~mm}$ high and $14 \mathrm{~mm}$ wide, nematocyst clusters become prominent as small papillae. Pedalia, wider than those of the former medusa, have marked nematocyst clusters arranged in two rows. Velarium provided with 2 or 3 simply branched velar canals in each octant. In this medusa the anlages of interradial mesenteries appear as interradial membraneous edges and thin lamellar gonads appear on the whole length of the interradial suture. After this stage, with the increase of medusan size, main changes are noted in repeated branching of velar canals, enlargement of gonads and gradual formation of interradial mesenteries. In a medusa, $24 \mathrm{~mm}$ high and $23 \mathrm{~mm}$ wide (Fig. 4), gonads more enlarged and the mesenteries fairly developed. In this stage gastral filaments are arranged in a wide row in the interradial part. The interradial mesenteries are well-developed in a medusa, $29 \mathrm{~mm}$ high and $21 \mathrm{~mm}$ wide. So far as the writer is aware, gastral filaments gradually reduce in number in later stages and seem to disappear at least in a welldeveloped medusa, $220 \mathrm{~mm}$ high and $135 \mathrm{~mm}$ wide, collected in the Inland Sea in winter.

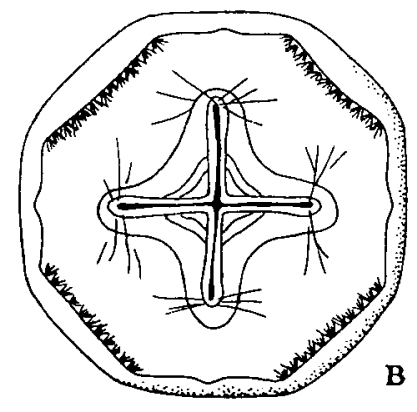

Fig. 4. Tamoya haplonema MÜLleR; A medusa, $24 \mathrm{~mm}$ high and $23 \mathrm{~mm}$ wide, with gonads and anlages of mesenteries; A. Side view. B. Aboral view, showing anlages of perradial mesenteries. In this specimen large prominent nematocyst clusters are distributed on the whole exumbrella. The large cubomedusa is very injurious to fishermen in autumn and winter. It is called "hikurage", fire-medusa. The cubomedusa, Carukia barnesi, newly described by Soutнсотт (1967) has possible interradial gastral filaments in the youngest stage.

\section{Tripedalia cystophora CONANT}

\section{(Text-fig. 5)}

Tripedalia cystophora: ConANT, 1898, p. 5-6; MAYER, 1910, p. 514; Stiasny, 1926, p. 243; Kramp, 1961, p. 307.

Two specimens probably referable to this 
species were obtained near the Aitsu Marine Biological Station of Kumamoto University. One specimen $6.5 \mathrm{~mm}$ in diameter and $5.5 \mathrm{~mm}$ in height (Fig. 5). Pedalia $2.5 \mathrm{~mm}$ long and sensory organs situated $2.0 \mathrm{~mm}$ above the bell margin. Another specimen $6 \mathrm{~mm}$ in diameter and $6.2 \mathrm{~mm}$ in height. Umbrella cubic, slightly higher than wide in living state. Apical portion slightly elevated in preserved specimens. The surface is sprinkled with minute nematocyst clusters. Of three marginal tentacles in each perradius the middle one is the longest. Pedalia fairly developed. Velar canals in the velarium, 16 in one specimen and 24 in the other specimen, in the latter they assume more or less triangular shape as was described by former investigators. Gastral filaments numerous and arranged in a square-form. Gondas develop on both sides in the middle part of the interradial suture.

As to the location of gastral filaments Conant (1898) gave a figure in which they are limited at the interradial corners of the stomach, while in the writer's specimens, they are arranged in a square-shape. This difference is distinct, but it is possibly due to the difference in stage. As is stated above, Tamoya haplonema has many gastral filaments in young stages but the specimens of older stages seem to have lost the organs.

Tripedalia cystophola seems to be a small
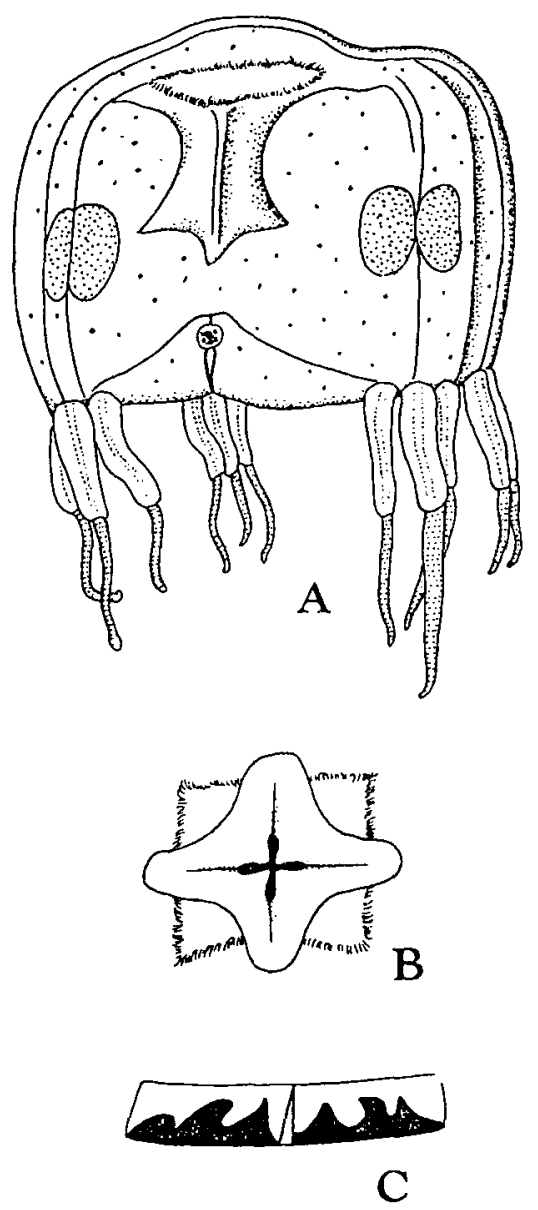

Fig. 5. Tripedalia cystophora Conant, $5.5 \mathrm{~mm}$ high and $6.5 \mathrm{~mm}$ wide; A. Side view. B. Oral view of manubrium, showing arrangement of gastral filaments. C. Velar canals of velarium.

premature tropical cubomedusa as in the case of Carybdea sivickisi. This species has hitherto been reported only from Kingston-harbour, Jamaica and the Philippines. This is the first record from Japan.

\section{LITERATURE}

Brgelow, H.B. 1938. Plankton of the Bermuda Oceanographic Expeditions. VIII. Medusae taken during the years 1929 and 1930. Zoologica, New York Zoological Society, vol. 23, p. 38-189.

Conant, F.S. 1898. The Cubomedusae. Mem. f. Biol. Lab. Johns Hopkins Univ., IIV, 1, 1-16, pl. 1-8. 
KRAMP, P.L. 1956. Medusae of the Iranian Gulf. Videns. Medd. f. Dansk nat. Foren, Bd. 118, p. 235242.

KRAMP, P.L. 1961. Synopsis of the medudae of the world. Jour. Mar. Biol. Assoc., vol. 40, p. 1-469.

Kramp, P.L. 1968. The Scyphomedusae collected by the Galathea Expedition 1950-52. Vidensk. Medd. Dansk naturh. For., vol. 131, p. 67-98.

MAyer, A. 1910. Medusae of the world, vol. 3. The Scyphomedusae, p. 499-735.

SouthcotT, R.V. 1967. Revision of some Carybdeidae (Scyphozoa: Cubomedusae), including a description of the jellyfish responsible for the "Irukandji syndrome". Aust. Jour. Zool., vol. 15, p. 65171.

Stiasny, G. 1922. Die Scyphomedusen-Sammlung von Dr. Th. Mortensen nebst anderen Medusen aus dem Zoologischen Museum der Universität in Kopenhagen. Vidensk. Medd. Dansk naturh. For., Bd. 73, p. 513-558.

Strasny, G. 1926. Ủber einige Scyphomedusen von Puerto Galera, Mindoro (Philippinen). Zool. Medd. S Rijks Mus. Nat. Hist. Leiden, Deel 7, p. 239-248.

Uchida, T. 1929. Studies on the Stauromedusae and Cubomedusae, with special reference to their metamorphosis. Jap. Jour. Zool., vol. 2, p. 103-193.

Uchida, T. 1947. Some Medusae from the Central Pacific. Jour. Fac. Sci., Hokkaido Imp. Univ., Ser. 6, Zoology, vol. 9, p. 297-319. 